\title{
Breast muscle topography and its relationship to muscularity in Pekin ducklings
}

\author{
Karima A. Shahin* \\ Department of Animal Production, Faculty of Agriculture, Ain Shams University, \\ P.O. Box 68, Hadayek Shoubra, 11241 Cairo, Egypt
}

(Received 23 March 1998; accepted 5 February 1999)

\begin{abstract}
One hundred and forty-four Pekin ducklings were used in this study. Weight, length, width and area of breast muscles ( $m$. pectoralis superficialis, $m$. pectoralis profundus) were used to examine their usefulness as predictors or indices of total carcass muscle weight. As much as $65 \%$ of the variation in total carcass muscle was accounted for by $m$. pectoralis superficialis area and length and the residual standard deviation was $22.1 \mathrm{~g}$. The combination of muscle dimensions with muscle weights resulted in a small improvement of the prediction of total muscle weight over that afforded by using muscle weight alone ( $R^{2}=0.90$ vs. 0.92 ; residual standard deviation [RSD] $=11.7$ vs. $10.8 \mathrm{~g}$, respectively). The variance explained by $m$. pectoralis superficialis weight and length was $92 \%$ and the RSD was $11 \mathrm{~g}$, while the corresponding estimates explained by $m$. pectoralis profundus were $82 \%$ and $15.8 \mathrm{~g}$. These results showed that if muscle weight is available, a very slight increase is obtained in the predictive value of total carcass muscle by including muscle dimensions in the equation. (@ Elsevier/Inra)
\end{abstract}

\section{muscle weight / muscle area / muscle length / muscle width / total carcass muscle}

Résumé - Topographie des muscles pectoraux et sa relation avec la muscularité chez le canard Pékin. Les poids et mensurations (longueur, largeur et surface) des muscles pectoraux (m. pectoralis superficialis, m. pectoralis profundus) de 144 canards Pékin ont été déterminés afin d'évaluer leur pertinence comme prédicteurs / indices du poids total de muscles de la carcasse. Les résultats ont montré qu'un peu plus de $65 \%$ de la variabilité dans le poids total des muscles de la carcasse pouvait être attribué à la surface et la longueur du $\mathrm{m}$. pectoralis superficialis $(\mathrm{RSD}=22,1 \mathrm{~g})$. La combinaison dimensions + poids n'a amélioré que modérément la prédiction par rapport à celle obtenue avec le poids du muscle seul ( $R^{2}=0,90$ versus 0,$92 ; \mathrm{RSD}=11,7$ versus $10,8 \mathrm{~g}$, respectivement). La variance expliquée par le poids et la longueur du $\mathrm{m}$. pectoralis superficialis a été de $92 \%$ (RSD $=11 \mathrm{~g}$ ) tandis que celle correspondante du $\mathrm{m}$. pectoralis profundus était de $82 \%$ (RSD $=15,8 \mathrm{~g}$ ). Cette étude montre que si le poids des muscles est disponible, la valeur prédictive du poids total de muscles de la carcasse peut être légèrement améliorée en incluant dans l'équation de prédiction les dimensions des muscles. (@ Elsevier / Inra)

m. pectoralis superficialis / m. pectoralis profundus / poids total de muscles / canard Pékin

* Correspondence and reprints

Tél: 00 (20)2 4441711 ; fax: 00(20)2 4444460 


\section{INTRODUCTION}

The size and shape (dimensions) of muscles and bones are among the major determinants of the overall size and shape of a live bird or carcass. Breast conformation and yield is an important factor in selling both breeding and slaughter birds. Ricard [10] reviewed the effect of body shape on body composition and its usefulness for poultrymen, processors, and market demands and consumer appeal.

In mammals, there are conflicting reports on the effect of conformation or shape on body composition. Some researchers $[6,7]$ reported that conformation was a poor indicator of composition. On the contrary, others $[5,8,12]$ reported that animal or carcass shape was a significant factor in determining composition. In birds, the breast (pectoralis) muscles are the largest and the most valuable part of the carcass. Their shapes (plumpness, angle, cross-sectional area, width and thickness) are one of the major characteristics, which is commonly included among others in breeding programs of commercial breeders and in commercial classification. In chickens, Heath and Owens [3] reported significant relationships between weights and dimensions of broiler breast muscles and carcass weight. Chambers [1] noted that the breast muscle crosssection area was the best criterion of market grade in chickens. In ducks, muscle dimensions other than thickness [9] have not been used extensively and their relationship to muscularity are little discussed in the literature. Therefore, this study was designed to examine the usefulness of breast muscle dimensions (i.e. length, width and area) as predictors or indices of total carcass muscle weight in Pekin ducklings.

\section{MATERIALS AND METHODS}

One hundred and forty-four (equal number of males and females) Pekin ducklings, approximately $1683 \mathrm{~g}$ in live weight and 10 weeks of age, were used in this study. The birds were slaughtered by severing the carotid artery and jugular veins. After dry plucking, the birds were eviscerated. After dressing, the carcasses were stored at $-20^{\circ} \mathrm{C}$. Prior to cutting and dissection, the carcasses were thawed for approximately $18 \mathrm{~h}$ at $5^{\circ} \mathrm{C}$ while in their bags. The right sides were then jointed into the following commercial cuts: thigh, drumstick, wing, breast, neck and tail, as described by Shahin [13]. In each cut, the skin, subcutaneous fat, intermuscular fat, muscle and bone were dissected and weighed. The sum of these parts over all cuts gave the total side muscle, total side bone, total side skin plus subcutaneous fat and total side intermuscular fat.

After dissection, linear and area measurements were recorded for the right-side breast muscles ( $m$. pectoralis superficialis and m. pectoralis profundus), closely trimmed. The muscles were placed on a flat surface and the maximum length and width of each muscle was measured without stretching with a dial caliper. The surface area was traced on paper and the area was measured with an electronic planimeter. The data from males and females were combined since the two data dispersion matrices did not differ significantly (unreported data).

\section{STATISTICAL ANALYSIS}

For studying the relationship between breast muscle topography and total muscularity, the data were analysed using a stepwise multiple regression procedure (SAS [11]) according to the following model:

$Y_{i}=\beta_{0}+\beta_{1} X_{i l}+\beta_{2} X_{i 2}+\ldots \ldots+\beta_{p-l} X_{i p-1}+e i$ where, $Y_{i}=$ total muscle weight $(\mathrm{g})$ for the $\mathrm{i}^{\text {th }}$ animal; $b_{0}$ is a constant; $\beta_{1}, \beta_{2}, \ldots . . \beta_{\mathrm{p}-1}$ are regression coefficients to be estimated (parameters); $X_{i l}, X_{i 2}, \ldots ., X_{i, \mathrm{p}-1}$ are the individual muscle dimensions for the $\mathrm{i}^{\text {th }}$ bird and $e_{i}$ is the error assumed to be normally and independently distributed $\left(0, \sigma^{2}\right), R^{2}$ and residual standard deviation (RSD) statistics were used as indicators of predictive accuracy.

\section{RESULTS AND DISCUSSION}

Table I lists the means, standard deviations, the coefficient of variation and ranges 
for dissected side weight, total side tissue weights, muscle:bone ratio and proportion of total muscle occurring in breast muscles and dimension. Total side muscle ranged from 100 to $325 \mathrm{~g}$ with a mean of $236 \mathrm{~g} . \mathrm{m}$. pectoralis superficialis and $m$. pectoralis profundus accounted for 21.6 and $3.4 \%$, respectively, of the total carcass muscle weight. Area, length and width of $m$. pectoralis superficialis averaged $79.4 \mathrm{~cm}^{2}, 15.4 \mathrm{~cm}$ and $6.7 \mathrm{~cm}$, respectively. In chickens, Halvorson and Jacbson [2] reported the average length and width of $m$. pectoralis superficialis as 15.0 and $6.5 \mathrm{~cm}$, respectively, and those for $m$. pectoralis profundus were 13.1 and $2.4 \mathrm{~cm}$, respectively.

The dimensions of $m$. pectoralis superficialis were less variable (coefficient of variation $[\mathrm{CV}]$ ranged from $6.4 \%$ for length to $13.5 \%$ for area) than the corresponding dimensions for $m$. pectoralis profundus $(\mathrm{CV}$ ranged from $7 \%$ for length to $30.4 \%$ for width) (table I).

\subsection{Relationship between muscle topography and muscularity in Pekin duckling}

The product-moment correlation coefficients of muscle area, length and width with total muscle weight are presented in table II. Irrespective of muscle, the correlation between total carcass muscle weight and individual muscle weight was higher than that between total carcass muscle weight

Table I. Means, standard deviations (S.D.), coefficient of variation (CV \%) and minimum and maximum values for live and carcass traits in Pekin ducklings.

\begin{tabular}{|c|c|c|c|c|}
\hline & Mean & S.D. & $\mathrm{CV} \%$ & Range \\
\hline Live weight $(\mathrm{g})$ & 1682.6 & 209.6 & 12.5 & $1000-2100$ \\
\hline Dissected side weight $(\mathrm{g})$ & 469.3 & 76.1 & 16.2 & $257.4-618.2$ \\
\hline Total side muscle $(\mathrm{g})$ & 235.5 & 40.1 & 17.0 & $100.3-324.5$ \\
\hline Total side bone $(\mathrm{g})$ & 98.6 & 10.2 & 10.3 & $60.9-125.9$ \\
\hline Total side fat (g) & 135.3 & 43.7 & 32.3 & $47.3-258.2$ \\
\hline \multicolumn{5}{|l|}{$\%$ of live weight } \\
\hline Total muscle & 27.9 & 2.8 & 9.9 & $19.9-34.2$ \\
\hline Total bone & 11.8 & 1.0 & 8.7 & $9.0-14.9$ \\
\hline Total fat & 15.9 & 4.2 & 26.6 & $6.7-25.2$ \\
\hline \multicolumn{5}{|l|}{$\%$ of total muscle } \\
\hline Breast muscle & 27.8 & 5.5 & 19.8 & $11.9-40.5$ \\
\hline M. pectoralis superficialis & 21.6 & 4.3 & 19.9 & $9.1-32.2$ \\
\hline M. pectoralis profundus & 3.4 & 0.8 & 23.5 & $1.1-5.2$ \\
\hline \multicolumn{5}{|l|}{ Muscle dimensions } \\
\hline \multicolumn{5}{|l|}{ M. pectoralis superficialis } \\
\hline Area $\left(\mathrm{cm}^{2}\right)$ & 79.4 & 10.7 & 13.5 & $42-98$ \\
\hline Length $(\mathrm{cm})$ & 15.4 & 1.0 & 6.4 & $11.5-17.5$ \\
\hline Width $(\mathrm{cm})$ & 6.7 & 0.7 & 10.0 & $4.6-8.3$ \\
\hline \multicolumn{5}{|l|}{ M. pectoralis profundus } \\
\hline Area $\left(\mathrm{cm}^{2}\right)$ & 23.2 & 5.3 & 22.9 & $10-33$ \\
\hline Length $(\mathrm{cm})$ & 14.3 & 1.0 & 7.0 & $8.5-16.5$ \\
\hline Width $(\mathrm{cm})$ & 3.1 & 0.9 & 30.4 & $1.2-5.4$ \\
\hline
\end{tabular}




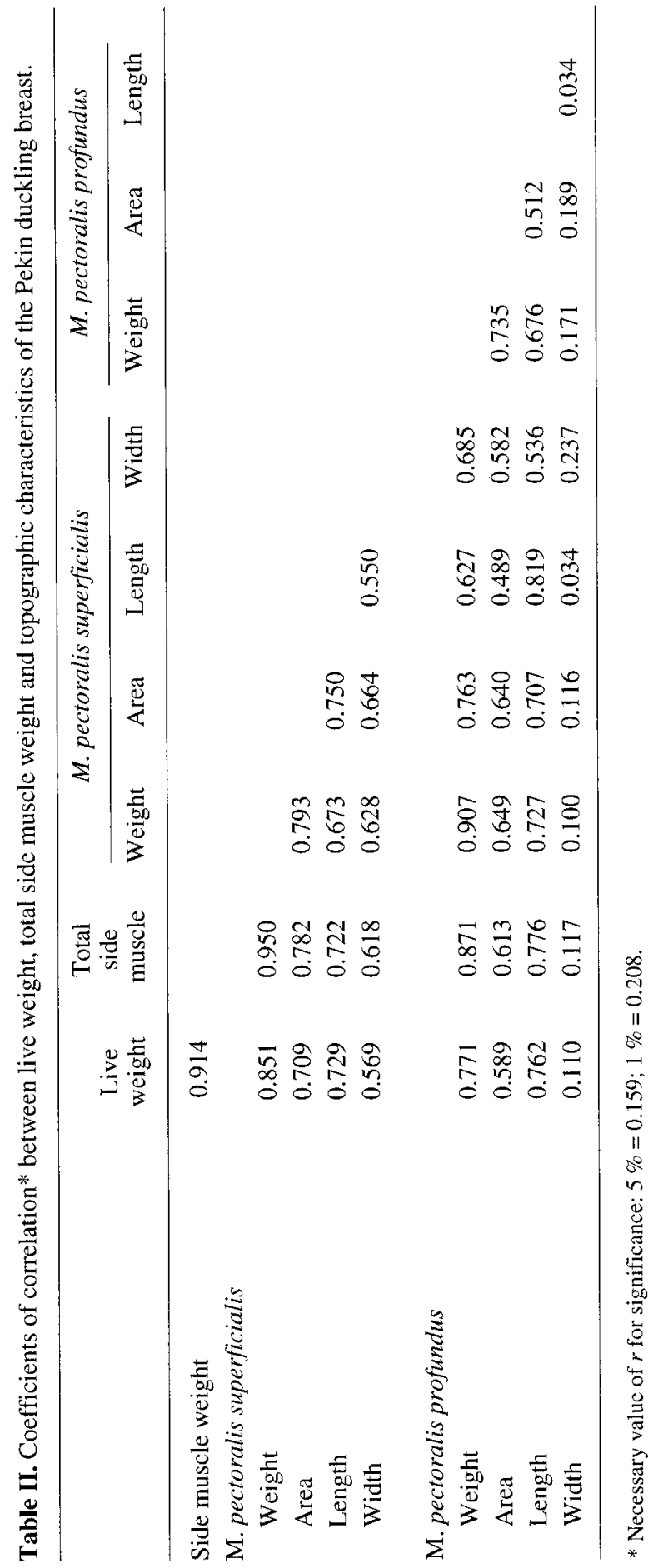


and each of the muscle dimensions. Total carcass muscle weight was correlated with m. pectoralis superficialis weight, area, length and width $(0.95,0.78,0.72$ and 0.62 , respectively), whereas corresponding correlations of total carcass muscle weight with $m$. pectoralis profundus were $0.87,0.61$, 0.78 and 0.12 , respectively. In chickens, Herstad and Frisch [4] obtained a correlation coefficient of 0.65 between breast width and breast meat. In ducks, Wawro et al. [14] gave a correlation of $>0.80$ between breast muscle weight and weight of lean tissue in the carcass. Pingel [9] reported positive correlations ( $r=0.41-0.59)$ between breast muscle thickness and breast muscle percentage of carcass.

\subsection{Prediction of total muscle weight}

Table III presents the results of multiple regression analysis for predicting total muscle weight from muscle weights and dimensions.

\subsubsection{Prediction of total muscle weight from breast muscle dimensions}

Results of regression analysis of predicting total muscle weight from breast muscle dimensions showed that $m$. pectoralis superficialis area alone accounted for $61 \%$ of the variation in total muscle weight and the RSD was $23 \mathrm{~g}$. The proportion of variance explained increased to $65 \%$ when the length of this muscle was added in the predictive model, and the RSD was then $22,1 \mathrm{~g}$ (table III). The present study showed that selected muscle dimensions were satisfactory predictors of total carcass muscle.

\subsubsection{Prediction of total muscle weight from $m$. pectoralis profundus weight and dimensions}

The $m$. pectoralis profundus weight alone accounted for $76 \%$ of the variation in total muscle weight, while the RSD was $18.3 \mathrm{~g}$
(Table III, part i). The proportion of variance explained increased to $82 \%$ when the length of this muscle was added, and the RSD was then $15.8 \mathrm{~g}$ (Table III, part ii). It is worth mentioning that this muscle is located between $m$. pectoralis superficialis and the sternum. This anatomical location makes it difficult to take its dimensions into account for prediction.

\subsubsection{Prediction of total muscle weight from $m$. pectoralis superficialis weight and dimensions}

The $m$. pectoralis superficialis weight alone explained $90 \%$ of the variation in total muscle weight, while the RSD was $11.7 \mathrm{~g}$. The proportion of variance explained increased to $92 \%$ when the length of this muscle was added to the predictive model and the RSD slightly decreased to $11 \mathrm{~g}$ (table III, part iii). These results showed that the $m$. pectoralis superficialis weight was the most important estimator of total carcass muscle weight, whereas its topography was of minor importance. If breast muscle weights are available, only a little increase in the predictive value of total carcass muscle mass is reached by including muscle dimensions in the equation. On practical consideration, the use of the $m$. pectoralis superficialis weight is more suitable than that of $m$. pectoralis profundus for estimating total carcass muscle because it is easier to remove from the carcass.

\subsubsection{Prediction of total muscle weight from breast muscle weights and dimensions}

Results of regression analysis for predicting total muscle weight from combinations of breast muscle weights and dimensions showed that the $m$. pectoralis superficialis weight alone explained $90 \%$ of the variation in total carcass muscle weight (table III; part iv). When the $m$. pectoralis profundus length was added to the predictive equation, the amount of variation explained 


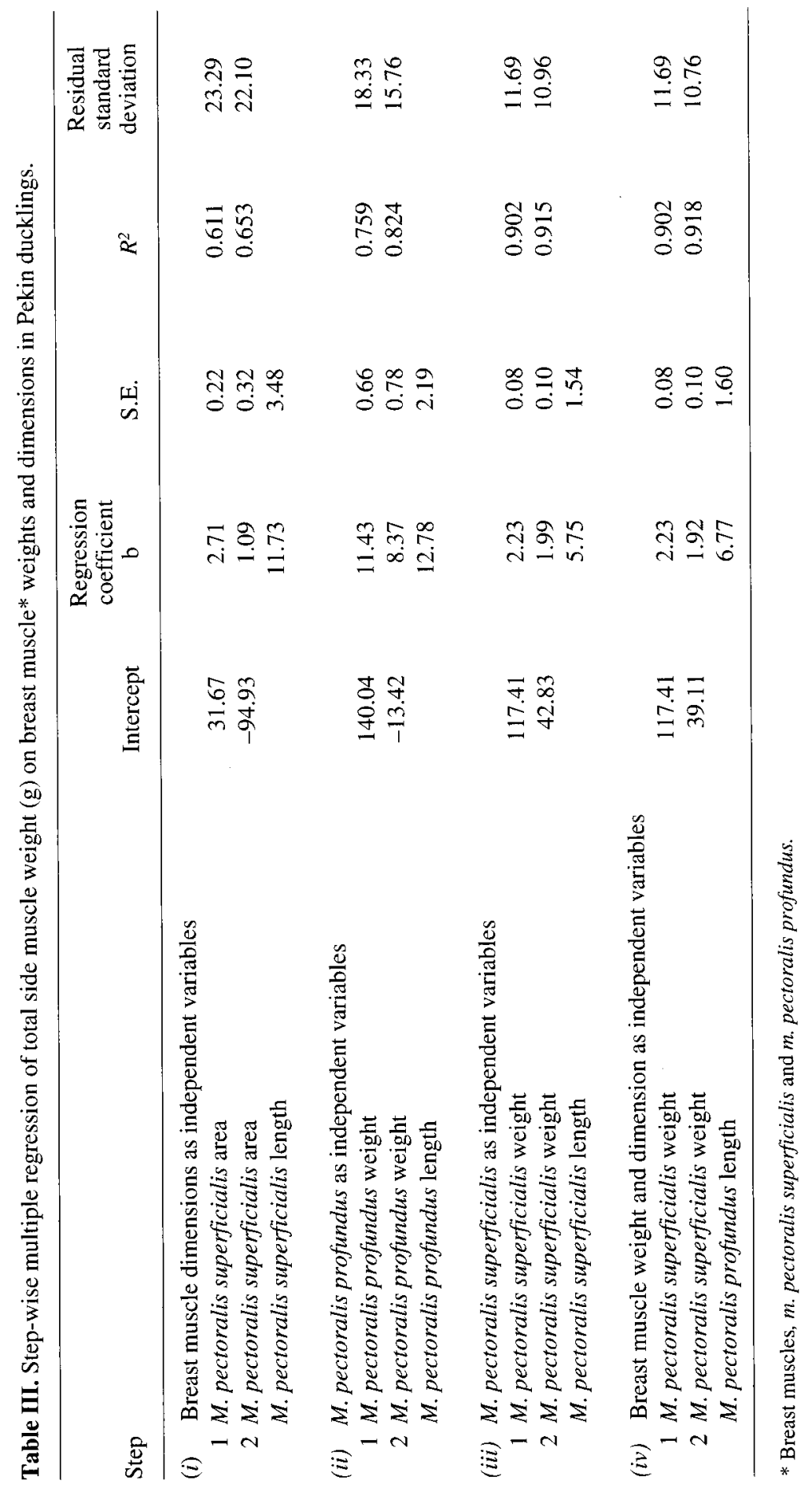


by both traits increased and the standard deviation of the estimate slightly decreased $(10.8 \mathrm{~g})$. Out of eight muscle weights and dimensions tested, two remained in the final equation:

Total side muscle weight $(\mathrm{g})=39.11$ $+1.92 \mathrm{~m}$. pectoralis superficialis weight $+6.77 \mathrm{~m}$. pectoralis profundus length $\left(R^{2}=0.92\right.$ and $\left.\operatorname{RSD}=10.8 \mathrm{~g}\right)$

It can be concluded from the available evidence that little knowledge was gained in the estimation of total carcass muscle weight by the use of breast muscle dimensions in conjunction with muscle weight, and that breast muscle topography is of no significant value when breast muscle weights are available.

\section{REFERENCES}

[1] Chambers J.R., Genetics of growth and meat production in chickens, in: Crawford R.D. (Ed.), Poultry Breeding and Genetics, Elsevier, Amsterdam, Oxford, New York, Tokyo, 1990, pp. 599-643.

[2] Halvorson D.B., Jacobson M., Variation in development of muscles in chickens, Poult. Sci. 49 (1970) 132-136.

[3] Heath J.L., Owens S.L., Dimensional relationship of selected broiler parts, Poult. Sci. 64 (1985) 318-327.

[4] Herstad O., Frisch J., Methods for estimating of meatiness and bone content in broiler carcasses, Acta Agric. Scand. 22 (1972) 17-21.
[5] Kaufman R.G., Grummer H., Smith R.E., Long R.A., Shooks G., Does live-animal and carcass shape influence gross composition? J. Anim. Sci. 37 (1973) 1112-1119.

[6] Kaufman R.G., Smith R.E., Long R.A., Bovine topography and its relationship to composition, Proc. Rec. Meat Conf. 23 (1970) 100-119.

[7] Kempster A.J., Cuthbertson A., Harrington G., The relationship between conformation and the yield and distribution of lean meat in the carcasses of British pigs, cattle and sheep: a review, Meat Sci. 6 (1982) 37-53.

[8] Martin E.1, Walter L.E., Writeman J.V., Association of beef carcass conformation with thick and thin muscle yield, J. Anim. Sci. 25 (1966) 682-687.

[9] Pingel H., Genetics of growth and meat production in waterfowl, in: Crawford R.D. (Ed.), Poultry Breeding and Genetics, Elsevier, Amsterdam, Oxford, New York, Tokyo, 1990, pp. 691-704.

[10] Ricard F.H., Carcass conformation of poultry and gam birds, in: Mead G.C., Freeman F (Eds.), Meat Quality in Poultry and Game Birds, Br. Poult. Sci. 1980, pp. 31-50.

[11] SAS, SAS User's Guide, Statistical Analysis System Institute, Inc., Cary, NC, USA, 1988.

[12] Shahin K.A., Sex differences in muscle topography and its relationship with muscularity in Double Muscled beef cattle, Livest. Prod. Sci. 43 (1995) 1-13.

[13] Shahin K.A., Analysis of muscle and bone weight variations in an Egyptian strain of Pekin ducklings, Ann. Zootech. 45 (1996) 173-184.

[14] Wawro K., Bochno R., Wawro E., The suitability of weight of some muscles for predicting tissue composition of carcasses of ducks slaughtered at different ages, Zeszyty Naukowe Akademii Rolniczo-Technicznj w Olsztynie no. 257, Zootechnika 27 (1984) 173-181. 